DOI https://doi.org/10.36059/978-966-397-117-9/220-246

\title{
CORRUPTION AND ORGANIZED CRIME IN UKRAINE
}

\section{Miniailo N. Ye.}

\section{INTRODUCTION}

According to the Article 1 of the Constitution of Ukraine our country is a sovereign and independent, democratic, social and legal state. These provisions are the basis for the development of not only legislation but the whole state of all spheres of its life. At the same timy in times of independence development and formation of our country is accompanied by numerous obstacles. As a result, today Ukraine faced a situation in which the main proclaimed postulates and principles of its formation and development remained on paper. And the reality requires immediate intervention and fundamental adjustments in order to actually achieve the level of a European developed and rule-based state.

The legal state is a form of government organization in which the rule in all spheres of life belongs to a legal law. In a legal state both state bodies and citizens are equally responsible before the law. It implements all human rights, the division of power into the legislative, executive, judicial. That is, it is such an organization of society in which the law and legal order take precedence over the state and other institutions of political and social power and not vice versa. And the basic rights of the person and his social security constitute the content of freedom, based on the laws that are subject to change in a lawful way.

In accordance with the Concept of reforming the criminal justice system of Ukraine, approved by the Decree of the President of Ukraine of April 8, 2008, No. 311/2008, at the current stage of development of Ukraine under radical changes in socio-political and other conditions prerequisites for reforming the system of criminal justice in the direction of further democratization, humanization, strengthening the protection of human rights and freedoms in accordance with the requirements of international legal acts and obligations of our state to the European and world community are formed.

In particular, this concerns the provision of the rights of participants in criminal justice, the expansion of the parties' adversaries, the rights of 
the victim, the elimination of the indictment in the activity of the court, the expansion of judicial control over the restriction of constitutional rights and freedoms at the pre-trial stage in criminal cases and appeals to the court decisions of the inquiry authority, the investigator and the prosecutor.

The problem of corruption remains one of the important and rather acute problems of our state today. In today's world there is no state that does not feel the influence of corruption. Over time only its volumes and expressions determined by the attitude of the state and society to it have changed. In Ukraine corruption is firmly established not only in the field of economics, politics, law enforcement but also negatively affects the social sphere, public consciousness, undermines the international image of the state, and thus hinders the consolidation of democratic foundations of society, promotes the development of crime and destroys the spiritual and moral values of society. This, undoubtedly, convincingly testifies to the relevance of scientific research, the subject of study of which is the problem of corruption.

Corruption in Ukraine, its scale and the extremely high level of perception by the population as an integral part of our state is a threat to Ukraine's formation as a legal framework. Having spread in all spheres of activity and functioning of the state, it has moved into the private sector as the established way of achieving the certain goals.

Effective counteraction to corruption is possible under the condition of the existence and functioning of an appropriate system of ensuring this activity, which includes a set of coordinated and interrelated measures of personnel, information-analytical, scientific-methodical, educational, material and technical and other character aimed at the proper implementation of strategic and tactical tasks in the field of combating corruption.

Corruption directly affects the development of Ukraine as a legal framework. Disregard for the law, manipulation of laws, distributed among law enforcement and judicial authorities, affects the attitude to the right of individual citizens, entails disbelief towards it and power in general. 


\section{Corruption as a threat to the rule of law}

The idea of a law-governed state is aimed at limiting the power of the state by law; to establish the rule of law, not people; on ensuring human security in its interactions with the state. Understanding the need for changes in the situation with ensuring human rights and freedoms in Ukraine and taking into account the European practice on these issues, our state is trying to reform its structures and legislation.

The existing system of criminal justice in Ukraine does not fully correspond to the new social relations developed in Ukraine and does not ensure the proper state of law and order, effective protection of individuals, society and state from dangerous encroachments on social values, rights and legitimate interests.

The system of criminal justice is somewhat cumbersome, internally controversial, not always scientifically sound and excessively complicated. The activities of its subjects are characterized by duplication of powers, the lack of a clear definition and delineation of their competence, giving priority to tasks that are in fact secondary, the application of unjustifiably complicated formal procedures. The criminal justice bodies have imperfect functional capabilities, which prevents them from observing the rule of law in their activities.

The system of organs traditionally called „law enforcement”, created as a mechanism for persecution and repression, has not been transformed into an institution for the protection and restoration of violated rights of persons. No effective measures were taken to reduce the level of corruption in this system.

Corruption in Ukraine has features that distinguish it from corruption in developed countries. Without revealing these features it is impossible to develop adequate measures to counteract it. Corruption in Ukraine today has the feature of the corruption of crisis type. This type of corruption is: a) generated by the crisis of modern Ukrainian society (and not only by the imperfection of criminal justice); b) able to deepen the crisis of Ukrainian society, having the ability to overthrow any political, economic, legal and moral reforms.

For today, corruption is a social phenomenon and an offense that has long roots. It arises as a result of the system of objective and subjective reasons and conditions. According to the results of sociological research in the field of prevention and counteraction to corruption, the main 
reasons and conditions for the emergence and spread of corruption in Ukraine are the imperfection of administrative services; creating excessive burdens for recipients of administrative services; insufficient level of integrity of persons authorized to perform state functions, inadequate effectiveness of authorized structures in terms of exposing and prosecuting perpetrators of corruption offenses, which has become a certain incentive for impunity.

The shadow economy and prices for goods and services are rising, in which the sellers pose unofficial payments, social inequality is established, and access to basic social services (free education, medicine, etc.) is reduced; leveling out the importance of education and professional achievements. In the end, the support of society is lost because of distrust of the population with corrupt officials. We have numerous plans, concepts and other legal acts against corruption, but to overcome this shameful phenomenon, there is a lack of basic - preventive work.

Corruption, if you can say so, has already become a way of thinking in our society. It rooted in all spheres of public life. In the public consciousness a system of corruption relations has been formed. It is necessary to change the style of thinking and the way of action. An important role in counteracting to corruption is to be provided by the media, to help them in a broad coverage of measures to combat this phenomenon, so that every shameful event becomes known to the general public.

It is necessary to form public support in preventing and counteracting this phenomenon, to organize educational work, in particular, to ensure that each educational institution conducts a course on the study of anticorruption legislation, scientific and methodological and scientificpractical conferences, seminars and meetings with representatives of law enforcement structures.

Current preventive work does not achieve the goal. On the prevention of corruption should be a set of measures - preventive, controlling, if necessary, operatively-wanted, investigators, proved in a legal manner to court decisions.

Among the search for directions and methods of combating crime and corruption, in particular, one should pay attention to strengthening the principles of legality, equality of all before the law and the rule of law in Ukraine. As long as there is no respect for the right in our country, all 
attempts to overcome corruption will be selective and mostly declarative. Establishing the foundations of a law-governed state requires a complex of measures that in their interconnection will bring positive results:

- abolition of immunities in respect of the prosecution of those categories of persons who own them;

- elimination of the selectivity of prosecution. The prosecution must be inevitable, but only if there are legal grounds;

- law enforcement bodies of the state should be truly "law" „guarded”, not repressive and punitive. In conducting proceedings in a case, one should not forget about the need to establish the truth in it, and therefore not only the facts proving the guilty person, and possibly its innocence;

- law enforcement agencies should not „compete” with each other, but cooperate in achieving the goals of their activities for the benefit of the entire state;

- selection of personnel for law enforcement and judicial authorities should be based on their professionalism, experience and qualifications;

- the court must become truly adversarial, where each party has equal opportunities in proving its righteousness with strict observance of laws in the most reasonable terms;

- at the state level, ideological propaganda of respect for the law and strict observance of its norms by all persons without exception should be carried out, with confirmation by this concrete actions of the authorities, since the education of the legal culture will require a long time.

Of course, the listed measures are not exhaustive. In addition, one should not forget that crime and corruption in particular are social and economic reasons, therefore, the introduction of respect for the right should go hand in hand with real economic transformations in the state and society, aimed at increasing social welfare of the population. and its security. Without the development of the economy, production and the growth of incomes of the general population, corruption will remain the main source of enrichment of citizens.

Ukraine has always been very active in cooperating with other states in the fight against corruption - an antisocial phenomenon that knows no boundaries and is inherent in the vast majority of countries in the world. The gradual accession of our state to international anti-corruption treaties became a political and legal response to the situation in the state. 
Nowadays Ukraine has acceded to three important international treaties which in its integrated form contain the world-wide practice of anti-corruption standards aimed at minimizing the socially negative consequences of corruption. In particular, it refers to the United Nations Convention against Corruption of 31.10.2003 (came into force on 01.01.2010 for Ukraine); Criminal Law of the Council of Europe on Combating Corruption of 27.01.1999 (came into force on 01.03.2010); Civic Convention of the Council of Europe on Combating Corruption of 04.11.1999 (came into force on 01.01.2006). Moreover, with the ratification of the latest, Ukraine has recognized itself as being under the control of the Group of States against corruption. Part of the fight against corruption is dedicated to the UN Convention against Transnational Organized Crime of 15.11.2000 (came into force for Ukraine on May 21, 2004), which considers corruption as the basis for the emergence and spread of such crime.

Participation of Ukraine in anti-corruption international treaties is aimed, first of all, at the formation of state-of-the-art ideas of corruption that are essential for the development of a modern anti-corruption legal policy, without which it is impossible to reform the national anticorruption legislation. In this connection, the need to bring the concepts (syllables) of the crimes provided for in the Criminal Code of Ukraine into conformity with the acts specified in the conventions and to make recommendations on the improvement of the regulatory framework in accordance with international standards remains in urgent need.

Thus, under the influence of the aforementioned international legal acts, the Law of Ukraine "On the Principles of Prevention and Counteraction of Corruption" in 2009, for the first time, provided a legal definition of "corruption": corruption is the use by a person of his / her authority and related capabilities for obtaining unlawful gain or acceptance of the promise / offer of such benefit to yourself or others or, accordingly, promise / offer or unlawful gain to such person or on his request to other natural or legal persons with a view to inclining this obu to unlawful use of authority given to it and related opportunities.

In addition, the anti-corruption world standards (in particular, the 1999 Criminal Law Convention on the Elimination of Corruption (Articles 7, 8) and the 2003 United Nations Convention against Corruption (Article 12)) require states to recognize criminal corruption in 
the private sphere. It is a deliberate provision of promises during the conduct of business, the offering or giving, directly or indirectly, of any unjustified advantage to any person who holds or works in private enterprises in any capacity, for them personally or for others persons in order to encourage them to perform or fail to fulfill their powers in violation of their duties.

Consequently, the provisions of the Criminal Code of Ukraine, which excluded the responsibility for the commission of corruption crimes in the private sphere, were revised. In particular, at one time, the Law „On Amendments to Certain Legislative Acts of Ukraine on Responsibility for Corruption Offenses" supplements the Criminal Code of Ukraine with a new section on corruption crimes in the private sector (Section VII-A „Offenses in the Field of Service in Private Law Entities and professional activities related to the provision of public services"). The legislator has identified the composition of such corruption offenses in a separate chapter, since responsibility for corruption in the public sector should be more rigorous than corruption in the private sector. This approach is also used in the criminal law of the United Kingdom, Iceland, Latvia, Luxembourg, the Netherlands, Poland, the Russian Federation, Slovenia, the USA, Finland, France.

Under the influence of world anticorruption standards, the legislation of Ukraine expanded the circle of subjects, which will be subject to liability for corruption offenses. In particular, it refers to such categories as officials of a foreign state or an international organization and persons who do not have the status of a civil servant, but perform public functions delegated by the state (auditor, notary, expert, lawyer, arbitrator, etc.). In turn, according to the UN Convention against Corruption, ,official of an international organization" is an employee of an international organization or any person authorized to act on its behalf. This approach is in line with the provisions of the UN Convention against Corruption (Article 2), the Council of Europe Criminal Law Convention on Combating Corruption (Article 1) and the Additional Protocol to it (Articles 2, 3).

On May 11, 2000, the Committee of Ministers of the Council of Europe adopted Recommendation No. R (2000) 10 recommending that the governments of the member states adopt national codes of conduct for officials based on the Model Code of Conduct for Public Officials and Local Self-Government Agencies annexed to this Recommendation. The 
Model Code provides for a number of rules to prevent the conflict of interests of officials, including the receipt of gifts.

In particular, Art. 18 of the Model Code states that an official can not demand or accept gifts, signs of attention, manifestations of hospitality or other benefits for himself or his family, close relatives and friends, or persons or organizations with which he has business or political relations that may emerge or appear to affect impartiality in the performance of official duties, or which are remunerated or appear to be remunerated in connection with his duties. This does not apply to generally accepted hospitality or small gifts.

It is important to note that the Committee of Ministers of the Council of Europe has instructed the Group of States against Corruption (GRECO) to monitor the implementation of this Recommendation. Therefore, Ukraine has to adhere to these standards, since it has entered into GRECO, and has assumed the corresponding obligations. At the same time it should be emphasized that the necessity of introducing similar norms exists not only because Ukraine has assumed respective international obligations. World experience suggests that setting limits on public service providers in obtaining gifts related to public duties is one way to prevent a possible conflict of interest.

Without these provisions none of the domestic anti-corruption systems will be effective. In addition, it is important to ensure public confidence in the public administration, confidence in its impartiality and justice. Certainly, such trust can not exist if citizens see that an official receives remuneration from one or another person for committing or refraining from committing certain actions in their favor. Taking into account the above, Art. 5 of the Law of Ukraine "On the Principles of Prevention and Counteraction of Corruption" limits the receipt of gifts for civil servants.

In addition, the Group of States Parties to the Council of Europe Against Corruption (GRECO), after investigating the anti-corruption legislation of Ukraine, recommended revising the system of administrative liability for corruption offenses in order to clearly establish that cases of corruption should be treated as criminal offenses or, as a last resort, clearly demarcate requirements before applying these two distinct procedures. Taking this into account the Code of Ukraine on Administrative Offenses was also changed. In particular, Chapter 15-B 
outlines the scope of corruption offenses in accordance with the Law of Ukraine "On the Principles of Prevention and Counteraction of Corruption" (in particular, obtaining unlawful benefits, bribery, unlawful assistance to individuals and legal entities, violation of requirements for the declaration of personal interests, etc.) and a clear distinction has been made between criminal and administrative responsibility for corruption.

Therefore, Ukraine's participation in international cooperation in the fight against corruption requires the full implementation of the norms of international anti-corruption conventions. The inconsistency of Ukrainian anti-corruption legislation with the ideology and core norms of anticorruption conventions can have negative consequences, in particular, because of the inability of a state's full-fledged presence in international cooperation in the fight against corruption, and hence the deterioration of the effectiveness of the fight against corruption at the national level.

In general, international anti-corruption standards have significantly influenced the development of Ukraine's anti-corruption legislation. This is especially true of those fundamental principles laid down by the Group of States against Corruption, which monitor the compliance of our state with the commitments it has undertaken to ratify the Council of Europe Convention on the fight against corruption.

The term „corruption” is no longer new and is used not only by scientists but also by the general public; it can be heard in the application not only in relation to persons who are in the public service, but also to entrepreneurs, technologists, scientists and others. And there is no doubt that corruption is closely linked to organized forms of crime, and sometimes it is an integral part of them. Thanks to corruption the organized crime of a certain country gets opportunities to spread its activities in the territory of other states, „captures” its territory. It is almost the most important determinant which predetermines the proliferation and security of the functioning of transnational criminal organizations.

Such a social phenomenon as corruption is closely linked to the shadow economy and often lies in the historical, cultural and political development of the state and society, its mentality. It exists in any state, has the ability to penetrate all power structures, thereby destroying their nature and preventing the implementation of various economic, social and 
other programs of government, destroying the very system of government in the country and opening the path to crime.

\section{Corruption and organized crime}

The Concept of Combating Corruption for 1998-2005, approved by the Decree of the President of Ukraine in 1998, states that „corruption feeds organized crime primarily in the economy, becomes an indispensable condition for its existence".

Along with other conditions, corruption allows organized crime to be protected from the influence of the state and its law enforcement agencies. Organized crime groups use a variety of corrupt acts that give benefits in obtaining real estate, contracting, avoiding punishment, etc.

The United Nations Convention against Transnational Organized Crime of 15 November 2000, states that corruption means a promise, offer or provision to a public official, personally or through intermediaries, of any unjustified advantage for the official himself or another person or entity in order for that official the person committed any act or omission in the performance of his official duties.

In addition, this extortion or acceptance by a public official, personally or through intermediaries, of any unjustified advantage for the official himself or another person or entity in order for that officer to commit any act or omission in the performance of his duties tries

But this definition is not universal, since it does not cover all possible acts that can be defined as corrupt.

The search for organized crime of new fields of activity and forms of influence on society leads to the search for organized criminal formations and new opportunities and ways of involving representatives of the authorities in the use of their official position for the benefit of both parties. In different countries corruption is manifested differently.

Developing countries are more likely to experience corruption that covers the entire system of government than developed countries. Often, this is due to the low level of consciousness in society, the perception of permissiveness and impunity, insufficient material provision, gaps in legislation, or its low characteristics, which enables criminal organizations to spread their activities and seize more and more new territories and spheres of activity. 
In developed countries corruption affects, in the main, some kinds of separate link (party, union, etc.), but the system of the developing country is less protected, especially because of low wages, therefore, organized criminal groups with significant funds easily get one or another form of support for their interests.

To a certain extent, corruption has a social conditionality, but as a result, negatively affects all spheres of life in the country. It destroys the economy, the attitude of people to power, thus reducing the nature of the state and its power structures. The culture and morality of the common people are also changing, as the phenomena of bribery, extortion and impunity among the power structures that are mirrorly reflected on the lower levels of governance become commonplace and memorized. One phenomenon generates another, there is a chain reaction and corruption itself has the ability to adapt to new realities, new power and new rules of the game.

Organized crime convincingly believes that everyone and everything has got its own price, and with such conviction attempts at bribes and rewards will never stop. And the change in this belief takes a long time, which often does not play in the interests of the authorities. It requires a change in the consciousness of society, the formation of the principle of observance and enforcement of laws for all citizens.

The term "corruption" comes from the combination of the Latin words soggei and rumpere (soggy - obligatory involvement of several representatives of one of the parties to the case, rumpere - to violate, break, damage, cancel). Over time, an independent concept corrumpere - was formed, meaning participation in the activities of several (at least two) individuals, whose purpose is to damage the process of managing the affairs of society. Another word of Latin origin coruptio means bribing, spoiling, corruption.

Thus, in general, under corruption we mean corruption of persons who provide management of various affairs, in particular state ones, their dishonesty and not objectivity, unfairness for any reasons in relation to their duties, search of their source enrichment.

M. Tikhomirov considers corruption as a criminal activity in the field of politics or public administration, the use by officials the rights and authorities granted to them for personal enrichment. He deals with bribery with officials and bureaucrats, bribery for the lawful or unlawful provision 
of benefits, protectionism - the nomination of workers on the basis of kinship, fraternity, personal devotion and friendship.

V. Ovchinsky binds corruption with bribing persons who are in the state or public service, receiving additional incomes, benefits and benefits for deliberate acts or inactivity (including in the interests of third parties) in contrary to the interests of the state and society.

A. Dolgova thinks that corruption is bribery of state or other employees and on this basis selfish use of them in personal or narrowgroup, corporate interests of official authority, the authority and capabilities associated with them.

O. Misery states that corruption, in its broad sense, consists in the decomposition of society and state when state (municipal) employees, as well as persons authorized to perform both state and other management functions, including in the commercial sector, use his official position, the status and authority of the position occupied, contrary to the interests of the service or other persons and established norms of morality, for selfish purposes for personal enrichment or in group interests.

Considering the issue of criminal liability for giving a bribe, V.S. Lukomsky points out that burglary of officials (bribery) is only one component of corruption.

This allegation is justified, especially in terms of understanding the connection between corruption and organized crime. Today organized crime formations are not limited to bribes, which may have the character of one-time payment of services or a series of payouts over a period of time, but form a long-lasting relationship. Of course, for organized criminal groups, the second option is better because they do not have to constantly establish new relationships and take risks with the search for new patrons. In addition, long-term payouts allow you to exercise and control an official and keep him from unwanted for organized groups of actions, often this control becomes blackmailed if a person tries to refuse further the provision of his services.

In order to reach highest level of activity criminal groups use other means and forms of influence, for example, the use of friendly relations, coercion, the assignment of relatives to senior positions, which gives significant benefits in concluding agreements, obtaining personal property, access to diverse values . Fraud, counseling services for officials 
with disproportionate payment for lectures and training, full material retention, extortion, etc. are used.

In addition, organized crime groups use corruption not only at the horizontal level, but also use it vertically, forming a strong link between officials in a government body and their representatives - corruption links. This allows them to provide certain stability in corruption relations, as well as the stability of ties, if the law enforcement bodies of the lower level corrupt person are exposed, the higher part of the criminals remains and the mechanism of their illegal activity remains indissoluble.

Corruptness, search and establishment of new corruption ties for organized groups is not only a necessary, but also vital part of their illegal activities. Corruption transforms the legislative field into the field of its own, informal relations at the state level, in the system of state power. And for organized criminal groups that seek to carry on their activities in other states, corruption in one state body is not enough, for them they need communications in various state bodies and at different levels.

V. Shcherban points out that corruption is only available where it becomes part of the management system - in many cases, it is so essential that the system does not function without it. The system of corruption is the weakest place for reformers, since the new government is unable to reform the system that it rules.

Realizing that there is a system of restraints and counterbalances between the branches of government, organized crime groups spread corruption in all branches of government. In addition, the appeal of prominent political and public figures who, due to their popularity, has access to the media, and thus to the possibility of convincing the general public of the legitimacy of certain decisions and actions, is of great importance. Criminals are often used by persons who enjoy a particular type of immunity, for example, representatives of embassies and consulates, deputies, missionaries, etc.

Thus, the understanding of corruption relations as a mandatory feature of organized crime, while understanding, not simply giving or receiving bribes for the provision of any service, but a constant connection of officials with organized criminals is logical and justified.

The danger of an organic combination of corruption and manifestations of organized crime has long been recognized by the international community. This is evidenced by the fact that the most 
influential international organizations, formulating recommendations for improving the effectiveness of the fight against organized crime, pay particular attention to combating corruption. Thus, in the 1990 Congress of the United Nations „Guidelines for the Prevention of and Fight against Organized Crime" explicitly states that ,the prerequisite for the development of crime prevention programs is the study of corruption, its causes, nature, consequences, the relationship with organized crime and measures to combat it".

In the United Nations Framework Convention Against Organized Crime of July 21, 1997, defining the concepts indicates that corruption is one of the three main means (two others, violence and intimidation), which enable organized crime leaders to obtain profits, control territories, external and internal markets, to continue their criminal activity and penetrate into the legal economy.

Establishing corruption links with public officials has always been among the priorities of organized crime, an integral part of their strategy and tactics, which was preferred to the use of open violence. The money paid in the form of bribes is considered to be the leader of a criminal world by successful investment, overhead, justified in terms of „advancement of business”, success and ensuring impunity.

From this standpoint, the most frightening and vivid example of attempts by representatives of organized crime to penetrate into public authorities and governance is the example of Bolivia, where one of the leaders of the local drug cartel nominated for the post of President of Bolivia, while offering to pay all the external debt of the country at 12 billion dollars in exchange for personal integrity and security for organized crime.

The penetration of representatives of organized criminal structures into state authorities and local self-government has the following main goals:

- evasion of leaders and members of transnational organized crime from criminal responsibility;

- neutralization of investigative actions, operational searches and other measures carried out by law enforcement agencies in respect of organized criminal groups or their individual members;

- provision of the so-called ,roof” for further criminal activity; 
- gaining opportunities for capital increase, obtaining other unlawful advantages, etc.

It should be noted that the presence of corrupt bonds for organized crime formations and the connection of a corrupt official with such formations is the optimal formula for the coexistence of the two phenomena in terms of achieving a criminal outcome and security. Transnational organized crime tries to gain a corresponding position in the power structures of its countries, and corruption, in its turn, is interested in using the opportunities of national organized criminal groups (financial, organizational, etc.).

Therefore, widespread corruption necessarily leads to an increase in organized crime, and the qualitative and quantitative development of the latter necessarily entails an increase in the number of corruption manifestations and increasing the danger of their nature.

An important point in determining the link between corruption and organized crime, as well as transnational organized crime, is their understanding of each other's inalienable elements. According to O. Gurov corruption should be understood as the constant connection of officials with organized criminals.

Such a constant link indicates that corruption is a systemic phenomenon that reflects the process of the flow of crime itself into power in the country and the decisions of its power structures.

At the same time, corruption acts as a process of struggle for power, expansion of power and influence, and a means of preserving the already acquired power. The higher the hierarchical graduate is an official, the more power she enjoys, and her corruption relationship with criminal organizations creates for them greater privileges and protection of interests. This is especially true for political leaders of the country, various influential political figures, as well as members of their family.

In general, politicians who abused their power can be distinguished by three grounds. They: commit offenses , in the name of law and the law", use their powers for criminal purposes, and therefore their abuse is difficult to detect and stop; use public opinion and trust; often used for the sake of their criminal purposes the state apparatus designed to fight crime.

The United Nations Convention against Corruption of October 31, 2003, ratified by Ukraine on October 18, 2006, uses the following terms:

(a) ,public official" means: 
- any person who holds a post in a legislative, executive, administrative or judicial body of a state which is appointed or elected, whose work is paid or not paid, regardless of seniority;

- any other person performing any public function, in particular for a public authority or state enterprise, or provides any public service as defined in the domestic law of the State and as applicable in the relevant field of legal regulation of that State;

- any other person designated as a ,public official” in the domestic law of the State. However, for the purpose of applying certain specific measures provided for by the Convention, "public official" may mean any person who performs any public function or provides any public service as defined in the domestic law of the State and as applicable in the relevant the field of legal regulation of that State Party;

b) "foreign public official" means any person who holds a position in a legislative, executive, administrative or judicial body of a foreign country that is appointed or elected; as well as any person who carries out public functions for a foreign state, in particular for a state body or state enterprise;

c) „official of an international organization” means an employee of an international organization or any person authorized to act on its behalf.

From these definitions of concepts, one can highlight the fact that they all relate specifically to public officials; persons who are called to perform any functions of the state, including at the international level. At the same time, each country has the opportunity to independently determine, in accordance with its domestic law, the range of those individuals whose actions may be subject to corruption.

Considering the practical understanding of the concept of corruption and its application, in particular, on the example of Germany, we see that distinguishing the following types of corruption:

- abuse of office for the purpose of enrichment (bribery, theft, other types of abuse);

- actions committed within the limits of official authority but in favor of specific legal entities or individuals;

- promotion of unfair competition, as well as disclosure of commercial secrets, which became known to one or another person in connection with the performance of its official functions;

- incorrect behavior of deputies (voting for remuneration, etc.). 
At the same time, by analyzing approaches to understanding corruption, we can observe some of its dual role. On the one hand, one of the signs of organized crime, and especially of a transnational character, is the existence of persistent corrupted ties with public officials. On the other hand, corruption is often seen as a separate form of illegal activity. So, L. Shelley, analyzing the state of corruption and crime in Ukraine, considers their dynamics separate, fixing the growth of both crime and corruption.

With this statement one can agree, in the case when corruption refers to the bribery-corruption of civil servants, their abuse of power by mercenaries or other motives (individual benefits, in favor of third parties - physical or legal).

But, from the above, one can see the relationship between the two indicated parties. In order for a bribe or other component of the act to take place, the party to be baptized should be available - organized crime, and especially transnational, is the party to that. It should be noted that the connection between them should be stable, long, and not one-time.

As A. Nikiforov, in the US, in every criminal family, there is, at least, one post of corruptor, and the established order, according to which about one third of the proceeds of crime should be directed to the corruption of the authorities and justice.

V. Lapteacru, based on the connection between the categories of concepts „bribery - bribe-bribery-corruption”, identified corruption as ,a process of unlawful behavior involving officials who occupy positions in all branches of state power, commercial and cooperative structures, and trade in the powers granted to them for various kinds of remuneration, services, benefits, etc., which decomposes state and non-state structures, institutions, administrative apparatus, turning them into a servant of the criminal world, as a result of which corruption became a social pathology".

As V. Yatsenko notes, ,corruption should be defined as a system of social ties of the criminal environment, primarily organized, which is manifested in bribery of state officials, misuse of their position for very useful purposes and other illegal actions, and provides the most organized crime favorable conditions for the implementation of illegal actions and the receipt of super-profits".

A. Dolgova notes the following signs in which corruption becomes an organized criminal activity of highly organized formations: 

roles;

- carried out thoughtfully, organizations with distribution of criminal

- in ensuring the secrecy of activities, including through clever ways to legalize criminal incomes and intimidating or eliminating unnecessary witnesses;

- with the purposeful creation of the most favorable conditions for organized criminal activity and expansion of the necessary corruption.

Issues of definition of the concept and essence of corruption are engaged, in particular, and American scientists. Thus, according to James Bellentine's Legal Encyclopedia Dictionary, corruption is distorting the designation of state bodies for personal gain. There are also such definitions as: a) an act committed for the purpose of granting certain advantages incompatible with the official duties of an official and the rights of others; b) the avoidance of political figures, employees of the state apparatus, businessmen and others from performing their official duties and government functions for the sake of personal, family or group interests in order to enrich and increase their social status.

The examples of definitions of corruption are rather interesting because they indicate that corruption is understood as the misuse of the advantages of its position not only by politicians and officials of the state apparatus, but also by business representatives.

According to Joseph Stieglitz, the president of the World Bank, corruption has many forms, and, consequently, the fight against corruption will have to be conducted on several fronts. It is impossible to fight the allocation of small sums of weak and poor countries, while ignoring the large-scale transfer of state resources to private hands, which took place, say, in Russia under Yeltsin.

In some countries, open corruption is primarily a form of contributions in favor of electoral campaigns, which oblige politicians to pay back to large donors for services in return. Small-scale corruption is bad, but systematic corruption in political processes can have even more devastating consequences. Contributions in favor of electoral campaigns and lobbying, which leads to the rapid privatization of infrastructure (before adopting the appropriate regulatory principles and attracting a small number of potential buyers), can be detrimental to development and without direct rejection of government officials.

In the context of the consideration of corruption as a factor-condition that determines transnational organized crime, it should be understood just in such a broad vision and not reduced to ordinary bribery. Since 
transnational organized crime is trying to get as much influence over state power in the country, and in order to conspiracy and legalize its illegal revenues, gain control of certain areas of business, their monopolies, it seems quite logical that these activities will contribute to the manifestation of corruption, which at the same time is also a means to achieve these goals.

At the same time, it should not be taken into account that the corruption link between crime and government and business may also be based on the mechanism of intimidation widely used by crime. So, in order to incline any official to an act in favor of crime, often intimidation, hostage-taking of members of their families, kidnapping of children, etc. are often used.

Organized crime under the conditions of globalization, tries to influence and political life, lobbying for making it profitable solutions, creating public opinion with the help of controlled media. All this happens against the background of bribery and the elimination of disadvantaged persons. Organized criminal gangs undermine democracy through corruption, and in some countries, their activities are becoming a new form of authoritarianism. Organized crime also negatively affects political life.

Accumulated funds go to bribe politicians, create a positive image in society, and so on. The aspiration of political power characterizes a qualitatively new stage in the development of organized crime. In this context, one can cite the example of the Sicilian and American Mafias, the Japanese Yakuza, Colombian drug cartels. " "We do not kill judges or ministers, we buy them," said the leader of the Colombian cartel Kali Hilberto Rodríguez Orehuela.

Corruption generates such negative phenomena as awareness of the population of the population of the state system, moral damage to society, a significant difference between declared and real values, inefficient allocation of resources, unprofitable spending of state budget funds, stimulation of lawlessness and the spread of criminal structures, usurpation of power, economic losses, etc.

The systematic bribery is ultimately enshrined in the organization of a clearly defined structure with established functions and control, and the merger of organized crime with political power constitutes an impediment to justice, leads to the theft of national wealth, the creation of privileges for dominant groups, the impact of criminal capital on state structures on 
the model of Colombia, the discrediting of ambushes free market, harm to investments, etc.

Organized criminal gangs have connections not only with state institutions, but also with prohibited political movements and terrorist organizations. In some parts of the world, organized crime has caused political instability and economic destabilization, wars of low intensity. As J. Nay rightly observes, corruption in many countries has become an integral part of national culture, a manifestation of a particular type of civilizational development that offends the categories of morality and law, thereby provoking its spread on an international scale.

The Transparency International Corruption Measuring Index (IPC) measures the level of perception of corruption in the public sector of a country and is a composite index based on surveys conducted among experts and business circles. Despite the fact that changes in the index occur slowly, significant statistical changes were noted in relation to some countries located throughout the CPI range, demonstrating both high and low results. Transparency International has underscored the unequivocal link between the high level of corruption and bribery with the failure of state institutions and the poverty of the population. However, even in those countries that are in a more privileged position, they are concerned about the differences in the application of anti-corruption legislation, which requires a tougher approach to the problem of combating corruption.

The basis of the favorable mentality for corruption is the life of Ukrainians on the principle of finding an individual solution to their problems, which is also a consequence of historical distrust of state institutions. Such mentality of Ukrainians helps to find ways to overcome their problems, and the opacity and complexity of permitting and control procedures in the relations between government and citizens contribute to the prosperity of such ways.

In Ukraine, the primary accumulation of capital by organized criminal groups occurred at the expense of purely violent criminal cases extortion, extortion, drug trafficking, etc. At the same time, the establishment of corruption ties or the direct delegation of criminality of "their people" to administrative, law enforcement or other decisionmaking bodies began. Subsequently, such persons at the expense of financial or other opportunities created the mode of the most assistance in promotion, so that the level of solved issues has increased. On the other hand, as practice shows, government officials often find contact with 
criminal elements that could sell their services more expensive and provide additional funding.

In the mid-1990s, one of the decisive trends in the development of the situation, which was observed in almost all regions of Ukraine, was already a certain withdrawal of criminal groups from open violent actions and traditional criminal crafts and directing them to direct or concealed participation in the legal business. Most criminal authorities tried to legalize the proceeds of crime through established or controlled commercial structures, where they occupied official but usually secondary posts, not related to material liability, and directed subordinate groups to use predominantly economic methods of generating profits.

More and more funds were invested in the establishment of special relations with those state functionaries, whose competence is to resolve important issues. By that time, about $60 \%$ of stable criminal formations had corrupt links in various power structures and administrations (about $40 \%$ of corporate executives and almost $90 \%$ of commercial entities' managers were in corruption relations).

Unlike the initial stage, when corruption links were established in order to ensure security in the implementation of specific criminal actions and those involved in them, there is a growing desire to acquire influential positions in public authorities that will allow them to effectively influence the adoption in the future. management decisions in their interests. With considerable material resources, representatives of the criminal environment directly participated in the elections, and sometimes they were elected by deputies of different levels, and so on.

Such a penetration of organized crime into power in Ukraine, both at the regional and central levels, has accelerated the formation of oligarchic clans, which, in turn, has become a powerful impetus for deepening the process of corrupting power - defending the interests of the clans, the authorities inevitably turned into corrupt, criminal. The logical conclusion of this process was that in some regions and industries the right to own and dispose of the real values of society almost completely turned into representatives or progenitors of organized crime.

In recent years, the process of integration of regional criminal groups into interregional and international criminal communities is becoming more and more crucial factor in the crime situation in Ukraine. Under the new conditions, criminal organizations from different countries of the world are trying to unite their efforts, which leads to the formation of transnational criminal communities. Diversification of criminal activities 
is noted. Organized criminal gangs tend to take control of all new spheres, spread the „exchange of experience”, improves the practice of illegal activities, security systems.

Large-scale corruption in power, economic structures, law enforcement and control bodies created a fertile environment for the development of these processes.

A special danger is the prevalence of criminal ties with corrupt law enforcers. In the past, it confirms that the active and long-term activity of organized crime groups, their vitality is largely contributing to the participation in them or ,patronage" by some law enforcement officers.

Law-enforcement agencies and crime, merging, create an environment in which effective struggle against illegal manifestations becomes almost impossible. These features are clearly traced in areas of transnational organized crime such as drug trafficking, smuggling operations, illegal migration and human trafficking.

Drug transactions remain the most profitable type of criminal business. Drug trafficking has become an important source of funding for transnational organized crime groups. Drug traffickers of Ukraine establish close cooperation with organized criminal groups of the Baltics, Russia, Poland and Turkey. Its illegal activities are carried out with the assistance of specialists in the chemical industry, professional pharmacists.

Corruption of controlling bodies, especially in the field of migration policy, the presence of a significant number of illegal migrants in Ukraine creates attractive conditions for the activity of drug structures. So, in the territory of our state and in the CIS countries there are racks of transnational organized criminal groups that unite immigrants from African countries (Nigeria, Ghana, South Africa, Sierra Leone, Cameroon, Angola, Ethiopia) and are involved in large-scale operations on illegal international drug trafficking.

The further spread is the formation of transnational organized criminal groups, which include both citizens of Ukraine and foreigners natives of our state. Structures of this kind set up channels for drug smuggling using Ukrainian territory, use our citizens as drug traffickers, involving local criminal structures in their activities.

Anti-smuggling, its negative processes continue to take place, acquire more sophisticated and organized forms, cause significant damage to the Ukrainian economy, to a large extent, destabilize the crime situation in the state. Transnational organized crime structures operating in this area are 
characterized by a dynamic response to changes in economic conditions, attempts to attract high officials, employees of state agencies and services, law enforcement agencies, qualified lawyers, etc.

Gradually structured and placed under the control of transnational organized crime formations and a kind of criminal business, such as the organization of the transfer of illegal migrants across the territory of Ukraine. There is a tendency to increase the "professionalism" of the organizers and to work out more sophisticated tactics for committing criminal actions.

The functioning of criminal mechanisms in the field of illegal migration is also largely provided by individual corrupt representatives of the authorities.

Foreigners who are illegally on the territory of Ukraine draw up foreign passports with constituent data of citizens of Ukraine and photographs of the customer, issue of false certificates of the established sample on registration, etc. Such unlawful activities involve a group of people, consisting of both executives and ordinary employees with a clear division of functions between them (coordination of actions, customer search, distribution of monetary remuneration, direct preparation of documents, etc.).

Trafficking in human beings and their use in criminal business is one of the key places in transnational organized crime. Due to a number of negative circumstances, Ukraine, among some other former Soviet republics, has become one of the main suppliers of the so-called "living" commodity.

Criminal business in the field of sexual services is being developed with the involvement of a number of functional units - private travel agencies, firms providing services for allegedly employment abroad, a network of recruiters involved in the search and engagement of women, groups that carry out shipment to destination countries, etc. Effective functioning of criminal infrastructure becomes possible again due to corruptions in medical institutions and law enforcement agencies.

The territory of Ukraine continues to be used by leaders of organized crime organizations of other countries to hide from the justice system. Corruption also serves as a favorable factor in establishing corrupt links in government and administration, the said persons receive legal passports on fictitious installation data (or installation data of third parties), official documents for the right to store gas and hunting weapons, rights to drive motor vehicles means legalizing this way in our country. 
In general, corruption as a condition for the spread of transnational organized crime is a rather complex phenomenon. On the one hand, it is one of the most prominent features that characterize organized crime, on the other hand, is a means to achieve the main objectives of criminal activity.

Corruption itself is a means that allows organized crime to become transnational, based on a new level of activity. Due to the corruption of certain representatives of foreign states, international organizations, transnational organized crime, new territories are emerging for the activity and the formation of markets for the sale of their goods and services.

It should be borne in mind that corruption also involves the possibility, or even the need to reward corrupt individuals for their activities or inactivity. Given that the level of development of different countries is unequal, as well as the funding of officials of their state apparatus, the standard of living of other members of society is different, and to live in abundance want to virtually everyone, such a material differentiation allows representatives of organized criminal groups to incline to their side the people they need, with the difference only in the type and amount of remuneration.

\section{CONCLUSIONS}

Ukraine is still a young state, not without errors in search for ways and means of its development, but in order to achieve its maximum heights and worthy representation on the international scene, it must definitely be a deep-rule state with judicial guarantees of the rights and freedoms of its citizens. The problem of corruption remains one of the most important and rather acute problems of our country today.

Corruption, to a degree, reflects both the state of society, its consciousness, the legal culture, the level of its moral and ethical development. Not only the state, but every citizen of the country, independently of the sphere of activity and occupation, should fight corruption, beginning with himself, rejecting and not allowing the possibility of involving himself in participation in any corruption acts. Unfortunately, in our society, the majority not only allows the possibility of corruption, but consciously aspires to it, thereby destroying any positive efforts of the state in establishing and improving the efficiency of its functioning in all spheres.

Current preventive work does not achieve the goal. On the prevention of corruption should be a set of measures - preventive, controlling, if 
necessary - operatively-wanted, investigators, proved in a legal manner to court decisions.

Along with other conditions, corruption allows organized crime to be protected from the influence of the state and its law enforcement agencies. Organized crime groups use a variety of corrupt practices that benefit from obtaining property, contracting, and evasion.

Organized crime convincingly believes that everyone and everything has their own price, and with such conviction, attempts at bribes and rewards will never stop. And the change in this belief takes a long time, which often does not play in the interests of the authorities. It requires a change in the consciousness of society, the formation of the principle of observance and enforcement of laws for all citizens.

In addition, organized crime groups use corruption not only at the horizontal level, but also use it vertically, forming a strong link between officials in a government body and their representatives - corruption links. This allows them to provide certain stability in corruption relations, as well as the stability of ties, in case of disclosure by law enforcement bodies of a corrupted person of the lower level, the criminals remain a higher link and the mechanism of their illegal activity remains inseparable.

Establishing corruption links with public officials has always been among the priorities of organized crime, an integral part of their strategy and tactics, which was preferred to the use of open violence.

The determining factor in the crime situation in Ukraine is the process of integration of regional criminal groups into interregional and international criminal communities. Under the new conditions, criminal organizations from different countries of the world are trying to unite their efforts, which leads to the formation of transnational criminal communities. Diversification of criminal activities is noted.

Ukraine on the way of active counteraction to organized crime, and now implementing and reforming the law enforcement and judicial systems, should maintain their effectiveness in the fight against and fight against crime, create the legal basis for qualitative interaction among themselves in achieving the ultimate goal. One of the priorities of its domestic policy should be the desire to effectively counter organized crime and minimize the negative consequences for society of its activities. 


\section{SUMMARY}

The article is devoted to the study of corruption and organized crime, their interconnection. Corruption is considered as a threat to the formation and development of a law-governed state. Corruption directly affects the development of Ukraine as a rule of law. Disregard for the law, manipulation of laws, distributed among law enforcement and judicial authorities, affects the attitude to the right of individual citizens, entails disbelief towards him and power in general. An overview of the connection between corruption and organized crime was conducted. Corruption feeds organized crime first and foremost into economic, it becomes an indispensable condition for its existence. Along with other conditions, corruption allows organized crime to feel protected from the influence of the state and its law enforcement agencies. Organized crime groups use a variety of corrupt practices that benefit from obtaining property, contracting, and evasion. It is indicated that corruption as a condition for the spread of organized crime is a rather complicated phenomenon. On the one hand, it is one of the most prominent features that characterize organized crime, on the other hand, is a means to achieve the main objectives of criminal activity. It is established that organized crime formations use corruption not only at the horizontal level, but also use it vertically, forming a stable link between officials in a state body and their representatives - corruption links. This allows them to provide certain stability in corruption relations, as well as the stability of ties, in case of disclosure by law enforcement bodies of a corrupted person of the lower level, the criminals remain a higher link and the mechanism of their illegal activity remains inseparable.

\section{REFERENCES}

1. Конвенція Організації Об’єднаних Націй проти транснаціональної організованої злочинності від 15.11.2000 // Офіційний вісник України від 19.04.2006 - 2006 р., № 14, стор. 340, стаття 1056.

2. Нуруллаєв I. С. О. Міжнародно-правове співробітництво в системі Ради Свропи у боротьбі 3 корупцією: Монографія / І. С. О. Нуруллаєв. - К.: Алерта, 2009. - 160 с.

3. Мельник М. І. Корупція - корозія влади ( соціальна сутність, тенденції та наслідки, заходи протидії): [монографія] / М. І. Мельник. - К., 2004. - 400 с.

4. Костенко О. М. Про концептуальні засади антикорупційної політики в Україні / Костенко О. М. // Політика в сфері боротьби зі 
злочинністю : Матеріали Всеукраїнської наук.-практ. конф. (1-2 березня 2013 року, м.Івано-Франківськ). - Івано-Франківськ : Прикарпатський національний університет ім. Василя Стефаника, 2013. - 307 c.

5. Скулиш Є. Д. Шляхи подолання корупції в Україні / Є. Д. Скулиш // ЮВУ. - № 32 (840).

6. Гуров А.И. Профессиональная преступность: прошлое и современность. - Москва: Юридическая литература, 1990. C. $205,215$.

7. Шнайдер Г.Й. Криминология: Пер. с нем. / Под общ. ред.. и с предисл. Л.О. Иванова. - М.: Издат. Группа «Прогресс» - «Универс», 1994. - С. 437.

8. Шелли Л. Организованная преступность и коррупция процветают в Украине // Трансформация. - 1999. - № 1. - С. 7.

9. Nye J. Corruption and Development: A Cost-benefit Analysis // American Political Science Review. - 1987. - № 67. - P. 411-429.

\section{Information about the author: Miniailo N. Ye.}

Candidate of Juridical Sciences, Associate Professor at the Department of Special-Legal Disciplines of the V. I. Vernadsky Taurida National University 33, Ivana Kudri str., Kyiv, 01042, Ukraine 